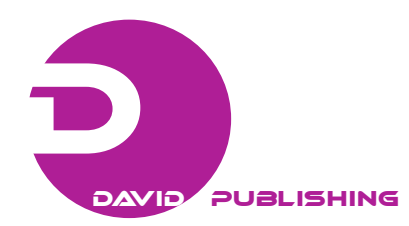

\title{
The Politics of Cultural Representation
}

\author{
Dionisio Nyagaa ${ }^{\text {, Rose Ann Torres }}{ }^{a}$
}

\begin{abstract}
This paper focuses on the representational politics of the Aeta indigenous women healers in Cagayan Valley in the Philippines. Indigenous peoples have been represented as backward, irrational, and consequently non-human. For racialized women, it is a double tragedy. They face race and gender misrepresentation. This identification interns them on the margins of society. This colonial representation is being questioned and subverted through the narratives of 12 Aeta women healers in the Philippines. In order to make clarifications as to how they have been represented, the Aeta indigenous women healers discussed and elaborated their indigeneity, language, and spirituality. In turn, they contrast their healing practices with public health. Their hope is to amend the way they have been signified. It is a point where the totalizing narratives meet the subjugated knowledge with a call for fairer representation. This paper confirms that Aeta women healers do not need external representation. They can represent themselves. In fact, they have already been representing themselves. The big question is, are we listening?
\end{abstract}

\section{Keywords}

Representation, healing, cultural representation, indigenous, Aeta women

Politics of representation is a major entry point for understanding our histories and who we have become. Foucault (1980) informed us to undertake historical excavation with the aim of unearthing past injustices to subjugated knowledge. We also need to understand how knowledge, power, space, and bodies have been created over time and how they work to undermine the "Other". Colonialism was a process of mapping spaces and bodies using the scientific method (Blomley 2003). According to Blomley, the frontier was seen as a space full of degenerates and one that needed civilization. It was a place that Hobbes and Locke would refer to as a state of nature. It was a world where everyone would live a solitary life independent of each other. Everyone was at liberty to do whatever they wished. These meant inhabitants of the frontier could kill each other at will. Hobbes called this a state of war which was nasty, brutish, and short. Negative liberty was the order of the day. Thus,
Hobbes called for the creation of a social scientific organization that would bring sanity. There would be the leviathan under which all would submit.

This was the reason the colonizer saw it fit to come to indigenous spaces and create social control. For this to happen, law had to be born. Law was seen as the leviathan. Liberty had to be seen as spatial terms, bringing the famous statement that "your liberty stops where mine starts". Law was an institution that created positive liberty such that one's freedom had its limits. Geometry as science was used

aUniversity of Toronto, Canada

\section{Correspondent Author:}

Dionisio Nyaga, University of Toronto, Ontario Institute for Studies in Education, 252 Bloor Street West, Toronto, ON M5S 1V, Canada

E-mail:

dnyaga.nyaga@mail.utoronto.ca; dnyaga@ryerson.ca 
to map physical spaces creating property (Blomley 2003). The surveyor would be used to create private space and erect a grind to signify the civilized and uncivilized. The division of the frontier was meant to empty the histories, stories, and practices of indigenous lands (Blomley 2003). The once natural spaces were divided into territories. This was meant to define who was in and who was out of a particular territorial space. This grid (Blomley 2003) was used to regulate the body through surveillance and threat of discipline and punishment. It was also a way to define, describe, and represent the other. The science of mapping was the science of representation. The process of disembodiment was key for representation to happen. The White man had to look at indigenous lands and its content from a disengaged gaze in order for him to name and identify them. That meant placing them in a space as scientific objects of investigation. To science, this was a way to be objective. This way of representing the other meant erasure of his past histories and practice in order to create the discovery of new lands. Indigenous peoples and their land were taken as objects to be discovered and represented. This was the start of the representation of indigenous peoples as social degenerates. This rational disembodied study informed and continues to inform academic research and understanding.

This discourse had been captured by Said (1978) in his discussion of the Orient and the Occident. The Orient has for a long time been represented by the West as violent and deviant. The Occident is identified as civilized and organized while the Orient is violent and disorganized. This representation was the start of colonial escapades in indigenous lands. The survival of the Occident relies on the existence of the Orient. Science and law have been used to define spaces and social bodies with the aim of eventual colonization. For that reason, the academy has played a major role in the misrepresentation of the colonized. Earliest researchers identified the indigenous peoples as subhuman and in need of a savior. This is the same discourse that continues to pervade many socio-academic and political discussions. This totalizing narrative (Foucault 1980) is now facing a backlash from the margins. The "subaltern" is speaking and we need to listen. Indigenous peoples want to be identified in their own terms and not those of the colonizer.

This paper therefore acts as a counter discourse to colonial misrepresentation of Aeta indigenous women healers. Drawing from their narratives on healing, this paper seeks to identify different ways in which indigenous healers in the Philippines want to be identified and defined. It represents their agency, resistance, and resiliency in the midst of colonial practices and liturgies.

This paper is based on the study of Aeta women healers and their healing practices in Cagayan Valley in the Philippines. It explores how the Aeta women healers talk about the issue of representation. It is apparent in the history of colonization and its aftermath that there is a great deal of work yet to be done in terms of documenting, classifying, and providing analysis to issues pertaining to how indigenous peoples are being represented. It is evident that indigenous peoples are systematically represented in a way meant to demonize and subjugate them. Representation has been used by the dominant social elites to maintain their hegemony. This supremacy is both an engineered and prized destruction on the memory and cultural practices that have so long been part of the Aeta and other peoples' cultural sojourns. To sustain their supremacy, the dominant elites in the Philippines have to make it their legal, educational, and administrative practice to functionally destroy the native identity, culture, and way of life and hence are frequently instrumental in the negative labeling of the Aeta and others who are resistant to their imposed knowledge. Again, the contrivance is the labeling of indigenous knowledge as "barbaric" and archaic.

Anticolonial, postcolonial, and indigenous feminist theories are critical in exposing how indigenous women 
are being portrayed in the current normative discourse (Spivak 1996; Smith 1999; Mohanty 1995; Green 2007). Indigenous women have been improperly represented in both literature and society. White feminist discourse often essentializes the experiences of Third World women without acknowledging their differences or the need to prioritize self-identification when involved in a political struggle. In this regard, Bhabha (1994) urged us to see the in-between and the beyond spaces of cultural diversity when looking at Third World women.

In this paper, the authors will examine the definition of representation. Then, they will discuss the background of the participants and the methodology that was used in the study. Then, they will explore the different factors on how the Aeta women healers have been representing themselves. In this section, they will look into their notion of indigeneity and language, spirituality and the indigenous healing practices versus public health. Then, they will conclude.

\section{DEFINITION OF REPRESENTATION}

Spivak (1996), whose works always focus on the interventions that change the world, asks how we can bring about change without repeating the mistakes of previous non-native investigators who, instead of bringing change for their "educative efforts", ended in failure. There is a way for Spivak to make a difference in society: by attending to the two definitions of representation, vertretung, meaning political representation, and darstellung, meaning "proxy" or representation in an economic sense. To combine the two meanings of representation is dangerous because, according to Spivak (1996), it will lead to a "fundamentalist mistake". This fundamentalist mistake entails representing constituencies based on an unstable identification like "the women", "the world", and "the workers". There is a ramification which stems from representing unstable identity, thus repeating the work of White feminism by universalizing the situation of Third World women. Nevertheless, for Spivak, vertretung and darstellung go hand in hand. Therefore, to resolve this dilemma, we need to use deconstruction because it acknowledges that in representation vertretung and darstellung are connected to each other, while simultaneously recognizing that there is complicity in doing this. Fundamentalists act as if this complicity does not exist (Spivak 1996).

This representation is important in this paper because it makes the authors conscious of how they represent the Aeta women healers. They have to be cautious about what they write about them. Moreover, they have to always remind themselves that they are complicit in what becomes written, as well as responsible for their actions. In the same way, Spivak is cautious about how representation is used.

The authors acknowledge the complexities of representing the Aeta women healers, but as long as they write and talk with integrity, the truth shall be divulged. Whose perspective are they going to use in defining truth? In this paper, they have to use the perspective of the Aeta women healers. Their purpose of representation is not just to counter the work of colonizationbut also to make known the knowledge and wisdom that the Aeta women healers possess, and to hear from them how they want to be represented.

Smith (1999) explained representation for indigenous peoples as both a political concept and reclamation of voices. With respect to political representation, colonization excluded the indigenous peoples from decision-making. For example, the colonizer expropriated the land of the indigenous peoples without considering their existence or input. The colonizer ravaged the lives of the indigenous peoples by taking away their women and children. They raped and used them in inhumane ways, while indigenous men were killed. Thus, for Smith, representation in the political sense is about exposing all these negative experiences which the indigenous 
peoples endured. Through representation, the voices of indigenous peoples can be reclaimed, because it is within this location that we talk about their bona fide story. The representation of indigenous peoples is a project of “countering the dominant society's image of indigenous people, their lifestyles and beliefs systems. It also proposes a solution to the real-life dilemmas that indigenous communities confront and (tries) to capture the complexities of being indigenous" (Smith 1999: 151). In representing indigenous peoples, there should be an acknowledgement of the different aspects of their lives. The indigenous peoples' successes and victories should be unearthed in order to counteract ideas about them, while simultaneously not romanticizing their lives.

\section{BACKGROUND OF THE PARTICIPANTS AND METHODOLOGICAL CONTEXT OF THE STUDY}

The author (Rose Ann) did a study with Aeta indigenous women healers in Cagayan Valley in the Philippines in 2010. Twelve Aeta indigenous women healers participated in the study. Although Aeta people have been identified with different names depending on their locations, the participants in this study identified themselves as Aeta who live in Cagayan Valley that is located in the northern part of Luzon, one of the main islands of the Philippines. Their ancestors lived in this place after they were displaced due to militarization from different lands in the Philippines. Most of the 12 Aeta indigenous women healers acquired their healing knowledges from their ancestors. They used herbal medicinal plants, oil, water, and prayers in healing.

As a methodology of this study, the talking circle has been used. The talking circle, according to Kovach (2009), "meant to provide space, time, and an environment for participants to share their story in a manner that they can direct” (Kovach 2009: 124). Graveline (1998) also had the same explanation about
Talking Circles, portrayed in her poem (136):

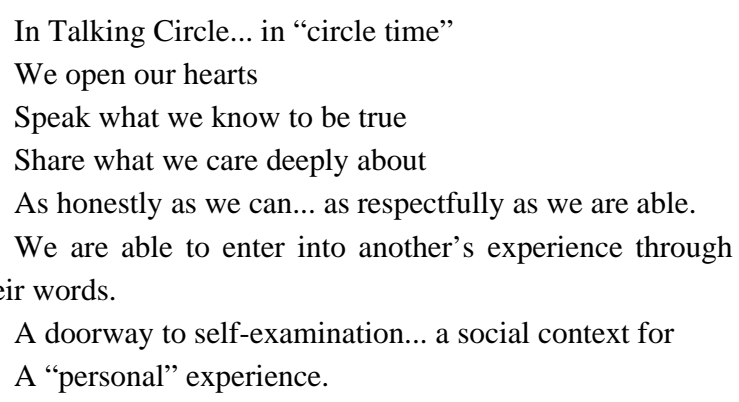

Aeta indigenous women healers did exactly the same during the study. The 12 Aeta indigenous women healers divided themselves into three groups. Each circle lasted for two hours. As a researcher and member of the circle, the author (Rose Ann) asked a question and whoever was ready to respond went ahead; the rest followed suit. The author was advised by the Aeta indigenous women healers to listen attentively instead of recording the conversation. As a researcher, she had to follow the wishes of the Aeta indigenous women. After each talking circle, she wrote what she had heard, including her reflection. She also went back to the community to validate what she had written.

\section{HOW AETA INDIGENOUS WOMEN HEALERS HAVE BEEN REPRESENTING THEMSELVES}

Knowing indigenous peoples have been shamelessly and incorrectly represented, the following question ensues: How do we correct and challenge colonial bias and ignorance? How can knowledge subvert ignorance and yield the most coherent method of representing the indigenous peoples, including the Aeta women healers? We submit—following many traditions including the Aeta-that the optimal formula is to focus on the value of telling stories and how these stories can be used to remedy faulty representation. This study emphasizes the immense need for telling the story of the Aeta as represented by their women 
healers-not just to attain recognition of their knowledge production but also to deconstruct the way they have been portrayed in literature. According to Spivak (1996), deconstruction:

...does not say there is no subject, there is no truth, there is no history. It simply questions the privileging of identity so that someone is believed to have the truth. It is not the exposure of error. It is constantly and persistently looking into how truths are produced. (Spivak 1996: 9)

In so doing, this paper explores how the Aeta women healers talk about their reality and how they want to be talked about. This is one of the representational forums that we currently lack. These troves of cultural and medicinal knowledge are not being acknowledged and are too frequently being misrepresented. By bringing clear, honest storytelling to the forefront (especially in the academy), we can have an authentically open discussion in which one can also question Eurocentric ways of knowing based on comparative methodologies. The Eurocentric knowledge can be subjected to evaluation that is not based on a single, predetermined endogenous model which conveniently conforms to its own political agendas. We can see the effects of various methods in their own representations. For instance, telling a story is not just about talking with a group of students in the classroom but also about writing and theorizing. What special characteristics of storytelling make this method a prevailing instrument in representing the Aeta? Smith (1999) explained storytelling:

Intrinsic in storytelling is a focus on dialogue and conversations amongst ourselves as indigenous peoples, to ourselves and for ourselves. Such approaches fit well with the oral traditions which are still a reality in day-to-day indigenous lives. Importantly, storytelling is also about humour and gossip and creativity. Stories tell of love and sexual encounters, of war and revenge. Their themes tell us about our cultures. (Smith 1999: 145)

Storytelling is a conversation amongst us. For the authors, the issue of representation is very political and thus they would like to share the history of the Aeta women healers in the public arena, such as the academy. They would like to share this history with their students, colleagues, friends, and the whole world, in accordance with how the Aeta want their culture presented. Why do we need to do this? If we do not take steps to highlight that they are and what their way of life is, we may potentially lead linguistic, cultural, social, and technical knowledge to extinction. We betray our children by depriving them, as the richness that is our ability as humans to learn, share, and preserve knowledge must be regarded. What could be a more important criterion for the evaluation of the utility of knowledge? What could be a better example of the best of humanity? By putting the Aeta and the rich tapestry of indigenous knowledge on the world map, we can bestow them with the sustainability and authenticity they deserve, and preserve, for both their and all our children, the bank of collective knowledge. The author knows that in claiming a voice in which to represent them, they have to be careful not to romanticize or essentialize the story and knowledge with which they have been entrusted.

Spivak warns that when one is telling a story of indigenous women's knowledge, with respect to strategic essentialism, one has to be careful not to purport that it holds the whims of universality. There is a need to emphasize that this knowledge is not the only knowledge in existence and that it is part of other knowledge. We can do this in the classrooms by hosting sessions whereby all the students are given the chance to talk about a story that they have learned from the ancestors in their respective communities. We have to encourage students to tell stories that are indigenous in nature, because having such a voice in the academic setting can be empowering and help dislodge the notion that there is only one voice (Caicedo 1997: 3). This is also the most ideal way of talking about the Aeta women healers' knowledge of ethno-medicine. In this paper, for example, the authors 
try to capture the ways in which the Aeta women healers perform their healing and why it can be called ethno-medicine. If this kind of story is invisible in the academy, it will be excluded from both the research agenda and the syllabus. Recall the final line by Wittgenstein at the end of his master work, Tractatus Logico-Philosophius. The line is particularly haunting in regard to knowledge lost or omitted: "Whereof one cannot speak, there must be silence" (Wittgenstein 1961). This project aims to assist in sharing the voice of the Aeta via the words and wisdom of the healers and thereby assist in ending the silencing of their negative representation in both the academic and official accounts.

The authors believe that the constructive act of documenting indigenous forms of healing, wisdom, and courage is a prerequisite in the process of sustaining resistance and dismantling the prejudiced objectives of the colonizer. By using postcolonial discourse analysis, the notion of "Orientalism" can explain how indigenous women have been marginalized in the knowledge production arena. The knowledge of the Aeta women healers has been negated and devalued in both history and the realm of knowledge production. From the perspective of indigenous feminism, we have to acknowledge the work and contributions of the Aeta women healers, which show how they have been stereotyped and devalued as members of the community. This does not suggest forgetting the work and the contributions of the men but rather highlighting that the Aeta women have been placed in subordinate positions by the colonizers despite having a particular and honored status in their own communities.

Singli, one of the Aeta women healers interviewed explains:

Representation to me is about helping the Aeta community and other people who are in need. We want to be represented the way we are. We want to change all the negative representation that has been written in books, magazines and textbooks because the misrepresentation has really destroyed our identity, the mind of our children and our future generation.

Singli explains the impact of negative representation on their lives. Although they have been representing themselves, there has been a problem of sanitizing institutions whereby the authorities have tried to subvert their image. Subsequently, each time there is a study about them, investigators, as well as their mainstream audience, always think that we are representing them. However, indigenous peoples have existed before colonization and before modernization. They were the first people in the Philippines. We acknowledge that they know more about the history of the Philippines than we do.

\section{INDIGENEITY AND LANGUAGE}

One of the paraphernalia in the colonization's battle plan is to destroy the indigeneity of the indigenous peoples and to annihilate their language. Colonial agents know that when the indigeneity of one human being is destroyed, the other parts of her or his life, including politics, will also be destroyed. The colonizer knows that when a person cannot speak his or her own language, it will be extremely difficult for that person to build the sense of his or her own culture or worldview. Eli Taylor, cited by Battiste (1998), states:

Our native language embodies a value system about how we ought to live and relate to each other... It gives a name to relations among kin, to roles and responsibilities among family members, to ties with the broader clan group... There (are) no English words for these relationships... Now, if you destroy our languages you not only break down these relationships, but you also destroy other aspects of our Indian way of life and culture, especially those that describe man's connection with nature, the Great Spirit, and the order of things. Without our languages, we will cease to exist as a separate people. (Battiste 1998: 18)

This analysis sees the holistic functions of language in an interpretive practice. Language is not 
just the words that we speak but also something that exemplifies our whole being. Thus, if we lose our own language, it is just like losing the genetic code of our community: We lose the operational blueprint for our hearts and souls.

The Aeta indigenous women healers talk about their indigeneity and language as powerful instruments when advocating for issues that have been affecting them. Wila explains:

I am an Aeta woman and I am not ashamed of it. I was born an Aeta and I will die an Aeta. Our language is different from that of the non-Aeta people, but we insist on our position in this society. For that reason, I must say I can speak my language even if they may refuse to listen to me. But, one way or another, they will hear me. Again, I am an Aeta woman, who possesses the language and the will to live forever.

\section{Rosa also states:}

I want to ask those people who know us to continue listening to us because, as time goes by, we have so many more things to talk about. We have so many stories to tell. Therefore, I want to continue talking and keep introducing my culture to people who do not belong to us. My language may be different; however, I believe that it is a powerful tool for communicating what we have.

Wila and Rosa explain the importance of their indigeneity and language. They state that through their language, they have developed/communicated a plethora of stories. These sets of memories constitute an oral library of Aeta cultural stores; these stories detail their resilience, agency, and struggles as Aeta women healers, as mothers, daughters, wives, and members of their community. Through their language, the Aeta women intend to send a message to listeners explaining that their healing is alive and that the healing can, therefore, be used by anybody who subscribes to its efficacy. Interaction with the Aeta healers exposes a healing knowledge that is not only useful for healing the physical body but also for promoting the emotional and spiritual well-being of a person. The women stress that their healing brings with it the power to change society as a whole because of the egalitarian nature of the Aeta inter-group practice by which the women healers do not choose whom to heal on the basis of skin colour, gender, religion, or class. Instead, they build cultural and medical bridges to anyone seeking their knowledge.

Talking with the Aeta indigenous women healers also makes it clear that their healing demonstrates the agency and resilience of the Aeta women who perform the healing. These Aeta women healers clarify that oppression, or pinangikuspil in Ilokano, can be explained depending on the social, spiritual, political, cultural, and racial location of a person. They have been represented as oppressed indigenous peoples in the Philippines, but they argue that locating them in this category of the "oppressed" is in itself oppression. They believe that, before giving them labels, it is necessary to understand the history of their struggles, resistance, resilience, and agency.

The Aeta women healers explained that in their own community, they may face certain problems and challenges, such as scarcities of food, violence or alcoholism, but also that they can practice their healing, perform their rituals, speak their language and be consulted in the decision-making process about their community. Their voices are being heard and recognized.

The Aeta do not categorize them as "maikuskuspil", or oppressed, when they perform all the aforementioned functions, including many other activities in their community that they are part of. They do not want to represent their community as flawlessbut rather want to convey that they have a community that is fair in terms of justice and recognition. In fact, they reflected on the impact of colonization: for example, the issue of private ownership. Some of the Aeta have started claiming that they own land, but according to their beliefs, no one has the right to own land. Everybody has the right to share the land with all the members of the 
community. Based on the above circumstances, some of the Aeta women healers assert that they are oppressed by structural elements in the Philippine hierarchy but empowered by Aeta indigenous women healers who maintain the cultural norms of their community.

They acknowledge that the moment they find themselves outside of their community, they experience oppression because they are not allowed to practice their healing, take part in the decision-making process in their country, be considered part of the public health system in the Philippines and freely perform their rituals in the public arena, such as in the city stadium. The voices are not being heard and their existence is not being acknowledged. It is for these reasons that they consider themselves oppressed by the non-Aeta community, a community that embraces the ideology of colonization. They understand these levels of power and the interplay and cultural dynamics that are present; thus, they want us to hear their voices.

Barnhardt and Harrison (1993) explained that "Language can serve as an important focal point for rekindling a sense of cultural identity and distinctiveness" (Barnhardt and Harrison 1993: 96). Wa Thiongo (1995) noted that:

Language was not a mere string of words. It had a suggestive power well beyond the immediate and lexical meaning. Our appreciation of the suggestive magical power of language was reinforced by the games we played with words through riddles, proverbs, transpositions of syllables, or through nonsensical but musically arranged words. So we learnt the music of our language on top of the content. The language, through images and symbols, gave us a view of the world, but it had a beauty of its own. (Wa Thiongo 1995: 287)

Language is very powerful in advocating various issues. Ngugi Wa Thiongo (1995), who chose to write in his mother tongue, Gikuyu, asserts that "Writing in the Gikuyu language, a Kenyan language, an African language, is part and parcel of the anti-imperialist struggles of Kenyan and African peoples” (Wa
Thiongo 1995: 267). In other words, as Achebe (1995) explained, "We play politics with language and in so doing conceal the reality and the complexity of our situation from ourselves and from those foolish enough to put their trust in us" (Achebe 1995: 269). Wila and Rosa are aware that their language may be different from that of others, but this is a source of pride. They recognize the power of their language. They are not willing to give up for the sake of being heard or to succumb to the convenience of others. They believe that they will be heard.

The Aeta women healers would like the non-Aeta people to understand that they, too, have their own identity and language. Their identity and language do not imply power and control over other people. For them, their identity and language speak are about "pinagkaykaysa" (unity) and "pinagkikinnaawatan" (understanding) among their people. It is because they understand the discourse in the society that they are open and willing to collaborate in the research. We call this representation in terms of identity and language. Since this is such a marvelous chapter in human group intelligence they also believe-rightly so that this knowledge should be featured in the academic discourse, as another perspective and area of study in libraries, and another topic of scholarship. Because they, as keepers, are so fully conversant with the richness, texture, and complexity of these stories and cumulatively acquired knowledge, they are confident that any potential reader will profit from, enjoy and indeed revel in learning about the Aeta women healers' language and identity as they do because it celebrates their living culture. It is a self-similar replication of the best in all of us; therefore, it can be deemed universal, precisely because of its ecologically and culturally specific roots.

\section{SPIRITUALITY}

One of the fundamental instruments of colonial 
brutality (sadly and ironically) was religion. The Spanish colonizers used religion because they knew that the indigenous peoples possessed sturdy spirituality. Trillana (2004) explained:

Pre-colonial natives of the archipelago believed in a unity of the spiritual and the material words. Purity of the inner self (Kalinisan ng Loob) led to harmony in the external order (family, community, society and nature). Conversely, the value of damayan (compassion and reciprocal assistance) reinforced these inner connections (among) members of the community. (Trillana 2004: 1)

The spirituality of the Aeta women centers around respect of both the visible and invisible. It is about having a fruitful relationship with your family, community, society, and nature. It is about helping each other in times of need and difficulty. In addition, the Aeta believe in the power of "ayat" or love. When love is possessed by a human being, harmony, good relationship, respect, and care come together. When colonizers entered the Philippines, they used Christianity as an implement to dismantle the spirituality of the indigenous peoples in the Philippines. Zaide (1957) pointed out how such indoctrination procedures stemming from foreign belief systems succeeded in creating a reorientation akin to psychological brainwashing:

Right from the inception of Spanish rule, Christianity took firm anchorage in the Philippines. By their exemplary virtues and spirit of Christian affection, the missionaries convinced the Filipinos of the falsity of their pagan gods and raised them to the light of the true faith. (Zaide 1957: 187)

Moreover, the Spanish not only imposed their own hegemonic teachings about Christianity but also destroyed the artifacts and sacred material belongings from the Filipinos. Guerrero (1974) described how the Spanish worked to achieve what they wanted from Filipinos:

...among the masses, the friars propagated a bigoted culture that was obsessed with novenas, prayer books, hagiographies, scapularies, the passion play, the anti-Muslim moro-moro and pompous religious feasts and processions. The friars had burned and destroyed the artifacts of pre-colonial culture as the handiwork of the devil and assimilated only those things of the Indigenous culture which they could use to facilitate colonial and medieval indoctrination. (Guerrero 1974: 15)

This is why documents and artifacts from the early Filipino peoples, among other things, no longer exist; this illustrates that the settlers' agenda was to impose their own culture. In addition, they did not only succeed in convincing the indigenous peoples that their spirituality was false, but they also dislodged the lives of indigenous women in particular. "As Fanon and later writers such as Nandy assert, imperialism and colonialism brought complete disorder to colonized peoples, disconnecting them from their histories, their landscapes, their languages, their social relations and their own ways of thinking, feeling and interacting with the world” (Smith 1999: 28). As a result, indigenous women have to counteract the heinous crimes done by the colonizer.

Aeta spirituality is rooted in their ancestors without any kind of colonial stain. It is pure and serves as a guide for building a loving and peaceful community. It destroys any notion of invading other communities and debunks any colonial mentality. It resists colonizing methodologies for knowledge production. It recognizes that men and women are equal. Furthermore, Watson (1997) described the nature of spirituality, stating:

All of life is spiritual. Even that which is considered material is of the Spirit if one believes... that everything comes from the Spirit, the Creator, the Giver and Source of all life. Spirituality is more than one's religious convictions; it is a way of life. (Watson 1997: 325)

The Aeta women healers explain their spirituality. Talna explains:

Our spirituality is about acknowledging the existence of our creator. We give thanks for everything that we have. We 
give thanks for the knowledge of healing. We give thanks for the gift of life. We give thanks for all the creation.

Maya also states:

Our spirituality is about believing in our Creator who gave us life. We do not believe in (having) power over other creations. We believe that every single thing in the universe has an equal significance in the eyes of God and in this world. It is also about respect for everything that exists in the universe. We denounce power and control, because we know that if these things exist in our way of life then we are destroying the essence of our spirituality.

Spirituality is embedded in their healing practices. Spirituality is part of their daily lives. It is about giving thanks to the Creator. It is about giving thanks to Mother Earth and for Nature's bounty. It is about giving benevolent thanks for the sun, the moon and the stars. It is about giving thanks for the gift of life, for family and for the relationships that exist in the universe. It is also about asking for forgiveness. Dei (2002) further explained that "Spirituality and spiritual discourses brought ideas and ontologies that emphasize connectedness, belongingness, identifications, well-being, love, compassion, peaceful co-existence with nature and among other groups" (Dei 2002: 5). Wangoola (2002) further reaffirmed that we are all connected by explaining that “...the unshakable belief that humans were but a weak link in the vast chain of nature, which encompassed the many animals, plants, birds, insects, and worms, and indeed inanimate things such as stones and rocks" (Wangoola 2002: 265). "The world was not for conquering, but for living within adorant harmony and reverence" (Wangoola 2002: 265).

The Aeta women healers' "credentials", which are to be represented, are based on their spirituality and the extensive experiential study of how this plays out in nature, medicine, and healing practices. Their spirituality is the source of their strength and power in the struggle against colonization. Their spirituality is an instrument for sustaining both their identity and agency. Their spirituality is one of their sources of healing. It gives them the confidence to heal and to perform their responsibilities as members of their community. They acknowledge their awareness of Christianity and attend to its truths rather than summarily dismissing it. In fact, they respect the teachings and recognize that it shares common truths with their own beliefs; we are, after all, human-all with the same strengths and flaws. Nonetheless, they would like to maintain the spirituality that they learned from their ancestors and sustain it despite having different struggles, oppressions, and dismissals. They would like to be identified by their spirituality because this would explain who they are and what morals and values they have in life. If the non-Aeta people appreciate Aeta spirituality, then the Aeta women healers believe that the stereotypes about the Aeta will cease.

\section{INDIGENOUS HEALING VS. PUBLIC HEALTH PRACTICE}

The history of Philippine medicine historically required the use of herbs and followed the belief that sickness was brought on by the spirits. Historians thus concluded that the earliest practice of medicine was in line with the indigenous healer practices (De La Cruz 1984). Nevertheless, when Spaniards established their colony in the nineteenth century in the Philippines, they brought with them physicians from Spain. Indeed, the creation of public health and Western medicine "were integral parts of the ideology of empire" (King 2002: 765). This "ideology of colonial healing" is one of the justifications given by colonizers for their invasion on the pretext that they were bringing the best quality of life for indigenous peoples. The idea that the Spaniards were out to save the newly found heathens from their uncivilized way of living was implanted in the minds of the indigenous peoples. Historically, it has not mattered if the colonizers ravaged, demonized, or dehumanized the lives of 
indigenous peoples. Colonial healing has been used to cover up the real work of colonization. In fact, history bears witness to several diseases in different countries where colonies were established. In other words, colonial medicine was a means of achieving the goal of colonization. The role that the indigenous healers have played was completely disregarded. Alfred Crosby (1972), in The Columbian Exchange: Biological and Cultural Consequences of 1492, forcefully argued that the main destructive effects of the conquistadors and other settlers were the introduction of alien animals, plants, and diseases, and that much of the project of genocide was operationally realized by these forces. In the case of North America, this led to over five million deaths and a radical alteration of population demographics, and subsequently paved the way for land expropriation, such as the "Manifest Destiny" in the United States. Similar analyses have been done and should be expanded to include the Philippines. In some ways, the Aeta were "protected" from earlier ravages by their comparatively remote location. Expansionism works on logic not unlike cancer: It is "sustained" by uncontrollable and unsustainable growth. In this respect, it is hardly surprising that all people, including the Aeta, are exposed to its acidic forces. The Aeta women's work is therefore linked in the deepest ways to the connections among nature, health, and society and is a counterpoint to what may be seen as the "crisis medicine" approach imposed by the West.

The Aeta women healers explain the differences between their healing practices and the Western way of healing.

Singli:

In my healing, I use herbal medicine and prayers. I believe that without the help of my Creator, the herbal medicine that I apply for my patient's body will be useless.

Holmes (2002) stated that "Ways of knowing are not based on the limits of one's own physical sense and may include prayer, prescience, dreams and messages from the dead" (Holmes 2002: 37). This notion has been affirmed by the Aeta women healers who state that their healing practice does not only focus on using herbal plants but also focuses on other ways of healing. Cena states:

Before I start healing, I ask my God to give me the wisdom so that I know which herbal medicine I should use. Through this, I get the courage to diagnose and at the same time give my patients the necessary herbal medicine.

Cena corroborates that she can diagnose diseases without going through any Western training and knows what herbal medicines she can prescribe for her patients. What Cena is trying to do here is tell us that her knowledge is authentic, as Hurtado (2003) explained, "The important thing was for the world to hear their hollering and to claim an intellectual space not by only complaining and deconstructing but (also) by being fruitful and multiplying” (Hurtado 2003: 218-219). Cena knows that by sharing her knowledge, she will be heard. She does not complain if others do not recognize her but rather continues to assert her place as an Aeta woman healer.

Other Aeta women healers explain their ways of healing. Rang-ay states:

I prepare my own medicine depending on the needs of my patients. I do not just heal the physical body but also the spiritual aspect. Sometimes you look at the patient and it seems that she is okay; in this, I can tell if it is the physical that needs healing, or (if it is) the spiritual or the emotional being.

\section{Aly also notes:}

Before a patient comes to me, I dream about him or her. So before I meet my patient, I already know the problem. However, I usually consult my patients first. I believe that I and patients have a way to heal her or him. Actually, I always give power to my patients to heal themselves. 
Wila further explains the difference between her healing and the Western way of curing diseases:

Aeta healing is not (only) about healing the physical body of a person but also about bringing that person back into a good relationship with the other creations. Our practices always encourage our people to be respectful to others. In our community among us healers we do not compete; in fact, we help each other. There are times that I need the help of my fellow healers to heal the sick, so I usually ask them to help me.

These observations bear witness to the fact that the Aeta women healers neither ignore nor compete with the public health healing system. They work on the basis of their worldview. Despite the knowledge that the Aeta women healers have, the public health system does not recognize them. Indeed, Philippine public health administrators are aware that having Western trained doctors and nurses in health centres does not adequately solve the health problems of the Filipino people. Gonzalez III (1998) has profiled some problems faced by this health care system, including "insufficient funds; lack of medical and paramedical manpower; inefficient use of scarce health services available; and lack of community support for health programs” (Gonzalez III 1998: 70).

The World Health Organization (WHO) and various United Nations entities have been giving out medical and humanitarian aid to the Philippines to treat different kinds of diseases. As much as this help is of immense importance, illnesses such as respiratory infections, tuberculosis, malaria and skin infections, still persist. The prevalence of such diseases has been worsened by the fact that "Despite the advancement of the medical system, they fail to reach the majority of those who are at risk, due to rising costs, and complex and expensive technologies that limit accessibility and availability of health care” (Marks 2006: 473). Tan (1987) had a different explanation of these health problems in the Philippines. According to Marks (2006), “The need to recognize plurality in our society is especially important for health care as it has become clear that the deficiencies of the health care system are partly rooted in our inability to understand even the most basic concepts of health and illness among our people" (Marks 2006: 1). Gonzalez III, who situates himself from a Eurocentric perspective, refutes these claims because Tan suggests recognition of the notion of health from the Filipino people, including the Aeta women healers. Other aspects of life, like spirituality and connectivity with the environment, play a marginal role in the contemporary health care arena. Non-recognition of these factors in the contemporary medicine world has been the cause for its minimal performance in seeking the precise way of curing illnesses among the population.

\section{CONCLUSIONS}

In conclusion, in spite of this shoddy treatment of the Aeta indigenous women healers, they still want to be represented on the basis of their healing practices, indigeneity, language, and spirituality. They believe that if they are represented based on the knowledge that they hold, the readers who do not know them will finally get to know and respect them. They want to change the negative characterizations about them. It is time to change the current norm into a reality: a reality that speaks honestly about the Aeta women healers. In fact, they believe that public health has played a tremendous role in helping people who are sick. The only concern they have is that public health is claiming to be the dominant player in curing diseases. For them, this claim is extremely problematic because they recall that empirically there are more diseases than before. Despite all the claims about the technical mastery of nature and science, the colonized people suffer from highly toxic ailments like high blood pressure, diabetes, and obesity, among others. Before the introduction of Western medical models and its monopoly over health care, which came with 
credentials and certification, these illnesses usually did not exist in their community, as the traditional Aeta person walks, climbs the mountain, eats fresh food and wild animals and drinks herbal medicines to cleanse his or her system. Increasingly, even in the West, it is now being understood that it is the body's immune system, not medical interventions per se, which sustain "wellness". All pharmaceuticals are, after all, chemicals, and all such chemicals are generally found in their most complex and useful forms in nature. The Aeta clearly embrace this principle and it is built into their practices. For example, aloe vera mixed with lemon juice and honey is issued for cleansing. For the Aeta women healers, representation is about writing and talking about their authentic identity; however, their identity is very much grounded in what the West glosses over as "scientific fact".

Through healing practices and knowledge production processes, Aeta women healers question the very authenticity of modern science. Given that they have been represented as outdated and in the frontier, Aeta women healers bring a new discursive framework of re-representation. They want to be identified in their own terms, so they are speaking. The question remains... are we listening? In most instances, indigenous healing is identified as crude, irrational, and emotional. Those who practice indigenous knowledges are deemed as non-human and devoid of wisdom. The spaces that they occupy are seen as wild and frontier. Those who practice indigenous healings are identified as natives. Being native means that they are immovable (Lipstitz 2007). It means that they can be contained. To that end, power, knowledge, and spaces come to define the identity of a colonial subject. For this reason, science has been implicated in defining the social bodies through colonial liturgies. Policies and laws are defined by that which is rational and empirical. As such, any knowledge that does not have rationality is dismissed in the policy-making table. This is the process that has been used to deny indigenous peoples of their rights and freedoms. Policies and laws created by science are used as panoptic tools to govern the indigenous peoples. Therefore, such policies have represented Aeta women healers as bodies living in the past, who need to be brought to modernity. These are the same colonial policies that have been used to deny their land claims. To that end, representation underlies extensive sociological realities that need to be keenly identified.

Aeta women healers are using their knowledge to call for their recognition. Through their healing practices and knowledge production processes, Aeta women healers are debunking colonial references to them as backward. They are countering the general colonial scientific representation of indigenous knowledges as lacking in rigor. Aeta indigenous knowledge comes out as a space to showcase their love for each other, their society and the living dead. It is a show of their respect to their ancestors by keeping their passed-on knowledge alive. Through healing, Aeta women healers exemplify their connection to their nature. Healing allows them to exert their resistance as shown in their narratives.

To that end, this paper calls for a re-reading of the "subaltern" knowledge production process as a new space for representation. This re-reading allows an understanding of the Aeta women healers as bodies that represent agency and resiliency. It is a new form of recognizing the power that lies in the margins. For far too long, people within the margins have been represented as powerless and non-resistive. Social edges have been incarcerated as spaces that need to be watched and unmovable. Aeta women healers have been identified as being in need of a saviour. In recent times, the field of social sciences has fallen into the same trap. We have identified the indigenous peoples as being in need of help; this after they have faced colonial control and annihilation. The talk has been that of an indigenous self that cannot sustain itself and is defenseless. This means of identification takes away 
their self-esteem and consequently renders them terminally interned. It makes them internalize oppression with the belief that it is natural to be oppressed. As a counter-discourse, this paper presents a discursive framework that identifies the strengths and power of Aeta indigenous women healers through their healing practices. It is a new way of reverting back colonial gaze with the intent of centering indigenous peoples as possessing power of self-representation. It is a way of un-doing Whiteness and science as master signifiers (Erickson 2011).

\section{References}

Achebe, C. 1995. “The Politics of Language.” Pp. 268-271 in The Post-Colonial Studies Reader, edited by B. Ashcroft, G. Griffiths, and H. Tiffin. London, England: Routledge.

Barnhardt, R. and B. Harrison. 1993. "Strategies of Education in Indigenous Communities.” Discourse 14(1):89-99.

Battiste, M. 1998. "Enabling the Autumn Seed: Toward a Decolonizing Approach to Aboriginal Knowledge, Language, and Education.” Canadian Journal of Native Education 22(1):16.

Bhabha, H. 1994. The Location of Culture. London, England: Routledge.

Blomley, B. 2003. "Law, Property and the Geography of Violence: The Frontier, the Surveyor and the Grid.” Annals of the Association of American Geographies 93(1):121-141.

Caicedo, S. 1997. "Decolonizing the Social Sciences: Other Ways of Knowing.” Presented at the CSSA Learned Society Conference, June, St. John's, Newfoundland.

Chase, S. E. 2003. "Learning to Listen: Narrative Principles in a Qualitative Research Methods Course.” Pp. 79-99 in Up Close and Personal: The Teaching and Learning of Narrative Research, edited by R. Josselson, A. Lieblich, and D. P. McAdams. Washington, D.C.: American Psychological Association.

Crosby, A. 1972. The Columbian Exchange: Biological and Cultural Consequences of 1492. Westport, CT: Praeger.

De La Cruz, J. 1984. Defending Our Inalienable Rights: We Cannot Fail Our Children. Retrieved (http://www.cwis. org/fwdp/Americas/joe).

Dei, G. 2002. "African Development: The Relevance and Implications of 'Indigenousness'.” Pp. 70-86 in Indigenous Knowledges in Global Context: Multiple Readings of Our World, edited by G. Dei, B. Hall, and D. Rosenberg. Toronto, Ontario, Canada: University Press.

Erickson, B. 2011. “'A Phantasy in White in a World That Is
Dead': Grey Owl and the Whiteness of Surrogacy.” Pp. 19-38 in Rethinking the Great White North: Race, Nature, and the Historical Geographies of Whiteness in Canada, edited by A. Baldwin, L. Cameroon, and A. KobayashI. Vancouver, British Colombia: UBC Press.

Foucault, M. 1980. Power/Knowledge: Selected Interviews and Other Writings, 1972-1977. New York, NY: Pantheon.

Gonzalez III, J. 1998. Development Sustainability Through Community Participation: Mixed Results Form the Philippine Health Sector. Aldershot; Brookfield, USA: Ashgate.

Graveline, F. 1998. Circle Works: Transforming Eurocentric Consciousness. Halifax, Nova Scotia: Fernwood.

Green, J., ed. 2007. Making Space for Indigenous Feminism. Halifax, Nova Scotia: Fernwood.

Guerrero, A. 1974. Philippine Society and Revolution. Hong Kong: Ta Kung Pao.

Holmes, L. 2002. "Heart Knowledge, Blood Memory, and the Voice of the Land: Implications of Research Among Hawaiian Elders.” Pp. 37-53 in Indigenous Knowledges in Global Contexts: Multiple Readings of Our World, edited by G. Dei, B. Hall, and D. Rosenberg. Toronto, Ontario, Canada: University of Toronto Press.

Hurtado, A. 2003. "Theory in the Flesh: Toward an Endarkened Epistemology." Qualitative Studies in Education 16(2):215-225.

King, N. 2002. "Security, Disease, Commerce: Ideologies of Postcolonial Global Health.” Social Studies of Science 32(5-6):763-789.

Kovach, M. 2009. Indigenous Methodologies: Characteristics, Conversations, and Contexts. Toronto, Ontario: University of Toronto Press.

Lipstitz, G. 2007. “The Racialization of Space.” Landscape Journal 26:10-23.

Marks, L. 2006. “Global Health Crisis: Can Indigenous Healing Practices Offer Valuable Resources?” International Journal of Disability, Development and Education 53(4):471-478.

Mohanty, C. 1995. “Under Western Eyes: Feminist Scholarship and Colonial Discourse.” Pp. 242-245 in Post-Colonial Studies Reader, edited by B. Ashcroft, G. Griffiths, and H. Tiffin. New York, NY: Routledge Taylor \& Francis Group.

Said, E. 1978. Orientalism. New York, NY: Vintage Books.

Smith, L. 1999. Decolonizing Methodologies: Research and Indigenous Peoples. London, UK: Zed Books Ltd.

Spivak, G. C. 1996. The Spivak Reader: Selected Works of Gayatri Chakravorty Spivak. New York, NY: Routledge.

Tan, M. 1987. Usug, Kulam, Pasma: Traditional Concepts of Health and Illness in the Philippines. Quezon City, Philippines: Alay Kapwa Kilusang Pangkalusugan (AKAP). 
Trillana, P. III 2004. "Rizal, Spirituality, and National Destiny.” Speech delivered at the Rizal Day National Breakfast, Order of the Knights of Rizal, Manila. Retrieved (http://findarticles.com/p/news-articles/manila-bulletin/mi_ 7968/is_2005_Jan_6/rizal-spirituality-national-destiny/ai_n 33956138/).

Wa Thiongo, N. 1995. "The Language of African Literature.” Pp. 263-267 in The Post-Colonial Studies Reader, edited by B. Ashcroft, G. Griffiths, and H. Tiffin. New York, NY: Routledge.

Wangoola, P. 2002. "Mpambo, the African Multiversity: A Philosophy to Rekindle the African Spirit.” Pp. 265-277 in Indigenous Knowledges in Global Context, edited by G. Dei, B. Hall, and D. Rosenberg. Toronto: University Press.

Watson, T. 1997. "Filipino Spirituality: An Immigrant's Perspective.” Pp. 324-332 in Filipino Americans Transformation and Identity, edited by M. Root. Thousand Oaks, CA: SAGE Publications, Inc.

Wittgenstein, L. 1961. Tractatus Logico-Philosophicus. London, UK: Routledge.

World Health Organization (WHO). N.d. Retrieved (http://www.who.int/en/).

Zaide, G. F. 1957. Philippine Political and Cultural History: The Philippines Since Pre-Spanish Times. Quezon City, Philippines: McCullough Printing Company.

\section{Bios}

Dionisio Nyaga, Ph.D. candidate, M.S.W, B.S.W, college instructor, Ryerson University, Social Justice Education, OISE, University of Toronto, Canada; research fields: men and masculinities, critical masculinity, indigenous studies, anti-colonialism, post-colonialism, anti-racism, African studies, trans-national and diasporic studies, anti-oppressive social work and practice.

Rose Ann Torres, Ph.D., Sociology of Education and Women and Gender Studies. Social Justice Education, OISE, University of Toronto, Canada; research fields: women and gender studies, indigenous studies/feminism, post-colonial and anti-colonial theories, transnational feminism, sociology of education, racial and ethnic relations, and culture. 